\title{
A Two-Step Model for Assessing Relative Interest in E-books Compared to Print
}

\section{Steven A. Knowlton}

\begin{abstract}
Librarians often wish to know whether readers in a particular discipline favor e-books or print books. Because print circulation and e-book usage statistics are not directly comparable, it can be hard to determine the relative interest of readers in the two types of books. This study demonstrates a two-step method by which librarians can assess the appeal of books in various formats. First, a nominal assessment of use or nonuse is performed; this eliminates the difficulty of comparing print circulation to e-book usage statistics. Then, the comparison of actual use to Percentage of Expected Use (PEU) is made. By examining the distance between PEU of e-books to PEU of print books in a discipline, librarians can determine whether patrons have a strong preference for one format over another.
\end{abstract}

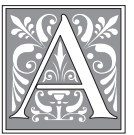

persistent challenge for collection development and assessment in academic libraries is balancing of monographic acquisitions between print and electronic formats. Each format offers distinct advantages and drawbacks. ${ }^{1} \mathrm{~A}$ common finding is that patrons use e-books and print books for different purposes and for different types of reading. For example, students may prefer print books for close reading with the goal of retaining information, but choose e-books for quick access to data. ${ }^{2}$ A recurring theme in the discussion of format choice is that librarians should consider, among other things, the preferences of their patrons.

Determining those preferences is another challenge. While, for example, an individual patron's dislike for electronic books (e-books) can be easily determined during a reference interview or even a casual conversation, it may be that the patrons who successfully access e-books from their homes do not report their satisfaction to a librarian. Stereotyped notions about the affinity for electronic materials of patrons studying technology-oriented subjects should also be questioned, simply as a matter of intellectual honesty. And librarians selecting large numbers of books may be unable to devote attention to books at an individual title level to assess whether anticipated use will be more likely to occur in print or electronic format. For these reasons, analysis of the demonstrated use of items in the collection can reveal more about the collective preferences of a library's patrons than can reliance upon anecdotal information.

The standard measurement of use for print monographs is circulation, although Ellis et al. have shown that many uses of print volumes are not captured by that method but

Steven A. Knowlton is Assistant Professor and Collection Development Librarian, University of Memphis Libraries: e-mail:steven.knowlton@memphis.edu. (c) 2016 Steven A. Knowlton, Attribution-NonCommercial (http://creativecommons.org/licenses/by-nc/3.0/) CC BY-NC. 
do appear in citation analysis and in-house use statistics. ${ }^{3}$ For all of its well-documented flaws as a measurements of a book's value in a library collection, the circulation of print books is easily captured and analyzed. ${ }^{4}$ Comparison of circulation between different areas of a collection is an established method of demonstrating the relative success of collection development in identifying materials that will be used by patrons. Collections with higher circulation are assumed to have more appeal to patrons. ${ }^{5}$

In principle, the tool of circulation analysis should help librarians identify those areas of the collection where patrons prefer e-books over print, and vice versa. Those fields in which e-books are used at a higher rate than print books should see the distribution of future purchases weighted more heavily in favor of e-books. However, technical difficulties make such comparisons nearly impossible.

E-book usage may be measured differently by numerous vendors, but typically providers count each time an electronic file is opened or downloaded. By contrast, print circulation requires the patron to make a special effort to transport a book to a circulation desk and take responsibility for returning it. So similar reader activities are counted differently in e-books and print.

For example, a reader flipping through the first few pages of a book to assess interest would count as an e-book usage, but not a print circulation. If a reader checks out a print book, she might open the book on several different occasions in the process of reading it through; however, the entire use of the book would only be recorded as one circulation. A patron accessing an e-book the same number of times (instead of downloading it) would, by contrast, register several uses. Many libraries offer varying checkout periods for different classes of users; at our institution, faculty members are allowed to check out a book for an entire year, and graduate students for an entire semester. Most e-book platforms allow a single checkout period for all users, and it is typically much shorter than a year. So, e-books may be available more days of the year than print books. Generally speaking, e-book usage figures probably overrepresent the interest of patrons in a book, while circulation figures probably underrepresent this interest. In any case, the disparity between the measurements makes it nearly impossible to reliably compare print circulation to e-book usage. Although Goodwin has distinguished "substantial use" of e-books from browsing-like use, and compared that to circulation, other problems detailed above persist in making useful comparisons difficult. ${ }^{6}$

Any effort to assess relative collective patron interest in one format over the other must overcome this obstacle of incompatible statistics. At the University of Memphis $(\mathrm{U}$ of $\mathrm{M})$, the main library is using a new method, described in this paper, to make that assessment. $\mathrm{U}$ of $\mathrm{M}$ is a comprehensive doctoral-extensive university, serving around 21,000 students in almost all academic disciplines with the exceptions of medicine and agriculture; more than 80 percent of students are undergraduates. The Law School administers its own library, but all other programs are supported by the University Libraries. The University Libraries' collections include more than 1,100,000 monographic volumes; but, in the last two decades, monographic acquisitions have dropped dramatically in the face of serials price increases. Out of a materials budget of more than $\$ 3,000,000$, in most years of the most recent decade monographic acquisitions have been less than $\$ 200,000$.

\section{Literature Review}

\section{Tools for Collection Assessment: Overview and Literature Review}

When assessing the relative strength and weaknesses of library collections according to discipline, librarians often use the statistics of circulation for print books and usage for electronic books. As discussed above, it is difficult to compare those two measurements across the two formats. However, examination of the raw numbers of circulation 
and usage leads to the observation that perhaps comparison of total numbers of circulation or usage may not be necessary to perform a useful analysis of the relative popularity of each format.

Table 1 shows the raw circulation and usage statistics, during academic year 2013-2014, of books published since 1990 in the collection of $\mathrm{U}$ of M. It is clear that books are far more likely to have not been used at all than to have experienced either circulation or electronic use. (This statement obviously disregards other measures of use such as in-house statistics and citation analysis.)

A chi-square test of these figures, which measures differences between actual results of a study

TABLE 1 Circulation Or Usage Of Books Published
Since 1990

\begin{tabular}{|c|c|c|c|}
\hline \multicolumn{2}{|c|}{ Print Books } & \multicolumn{2}{c|}{$\begin{array}{c}\text { E-books (EBSCO } \\
\text { Collection Only) }\end{array}$} \\
\hline $\begin{array}{c}\text { Number of } \\
\text { Circulations }\end{array}$ & Titles & $\begin{array}{c}\text { Number of } \\
\text { E-Book Uses }\end{array}$ & Titles \\
\hline 0 & 87,199 & 0 & 61,968 \\
\hline 1 & 8,134 & 1 & 4,071 \\
\hline 2 & 1,219 & 2 & 1,418 \\
\hline 3 & 235 & 3 & 726 \\
\hline 4 & 71 & 4 & 408 \\
\hline 5 & 15 & 5 & 248 \\
\hline 6 & 6 & 6 & 177 \\
\hline 7 & 1 & 7 & 122 \\
\hline 8 & 0 & 8 & 80 \\
\hline 9 & 1 & 9 & 62 \\
\hline
\end{tabular}
and the expected distribution of results, gives a $p$ value of $<.001$, meaning that these figures are very unlikely to have been produced by chance. That is to say, the differences between use and nonuse are statistically significant.

That observation about likelihood of any use has led many librarians to conclude that the problems of comparing levels of use may be disregarded. The datum of any use at all is enough to distinguish a book from its fellows in the collection. Comparison of that single attribute is easily made between print and e-books.

In statistical parlance, the total circulation or electronic usage figures are "marginal variables." That is, usage figures will vary depending upon a number of conditions. Those conditions might include whether it was assigned for course reading or placed on reserve, whether a book was returned when it was due, or the length of the checkout period. Each of those conditions, however, requires that the book be used in the first place. The total number of uses does not influence the probability that a book was used (as opposed to not used). ${ }^{7}$ Therefore, one can with some safety disregard the total number of uses in our analysis of relative patron interest in one format over another. The main question is whether the book was used at all. In a nominal analysis, data are sorted into one of two categories; in this study, the categories are "used" and "not used."

An early study that abandoned total usage and circulation figures to concentrate on the nominal attribute of use or nonuse was published by Connaway, Densch, and Gibbons in 2002. ${ }^{8}$ Analyzing only those titles that were available in both formats, they found that patrons at the University of Pittsburgh exhibited a preference for e-books.

Littman and Connaway used the same method at Duke University in 2004 and again showed that patrons used more of the electronic versions of titles available in both formats. They also identified those disciplines for which usage was highest in each format. ${ }^{9}$

Christianson and Aucoin in 2005 compared books duplicated in electronic and print formats in the Louisiana State University collection. ${ }^{10}$ Their test of whether electronic use predicted print checkouts found a low level of correlation between use of a book in one format and use in another format. 
A 2006 study by Williams and Best also compared whether a book was used or not and in which format, but only for titles reviewed in the book-selection journal Choice. ${ }^{11}$ At Auburn University at Montgomery, patrons showed a strong preference for print editions of books reviewed by Choice.

In 2009, Slater also compared use or circulation of books available in both formats at Oakland University. ${ }^{12}$ Although he calculated an "approximation of the number of users" for certain e-books, for the purposes of determining which collections were most well used, he simply compared whether a title was used in a given format. He was able to assess those disciplines where his patrons exhibited a strong preference for one format over another and also to determine whether "big deal" e-book packages justify their prices.

Bucknell in 2010 analyzed, among other data, subsets of the University of Liverpool's e-book collection. ${ }^{13}$ The point of comparison was how many titles had been used at least once in a given month. This allowed him to evaluate the level of interest in titles several years after publication.

Most recently, Rose-Wiles in 2013 extended her analysis to the entire collection at Seton Hall University. ${ }^{14}$ By measuring the rate of use or nonuse among both print and electronic collections (not restricted to titles held in both formats), she noted that, among science books, the two formats were used at very similar rates.

To date, most studies using the nominal analysis of use versus nonuse have been confined to sets of titles that were held by a library in both formats. While these results are valuable, they are based on relatively small samples of a library's collection. The obvious objection to the validity of such studies is that collections contain strengths in one format that are not matched in the other. For an assessment of patron format choices across the entire collection, a method that compares dissimilar sets is preferable.

\section{Percentage of Expected Use (PEU)}

There is a tool that has been used to assess a collection's appeal to patrons in different subject areas. It measures the amount of use in a particular subset of the collection and compares the section's percentage of the total use of the collection to the percentage of the collection represented by the subset. For example, if books on nursing represent 10 percent of a library's collection, use of nursing books should represent 10 percent of all the use of the collection. In areas where use exceeds the proportion of the collection, the library's collection in that field has more appeal to users than expected, and vice versa.

This approach was advocated by Bonn, who suggested in 1974 that the "ratio of use to holdings in specific subject classes" can "measure the intensity of use of all or part of the ... collection." ${ }^{15}$ In 1982, Mills refined the approach by suggesting that the proportion of use be compared to the proportion of the collection, producing a "percentage of expected use" (PEU). ${ }^{16}$ Aguilar expanded upon the PEU by suggesting in 1986 that collections with a PEU greater than one standard deviation from the mean (toward overuse or underuse) should be scrutinized as exceptions to normal use patterns. ${ }^{17}$ In 2002, Ochola demonstrated an application of PEU along with another of Aguilar's ideas, the "ratio of borrowings to holdings" (measuring interlibrary loan use), for collection evaluation. ${ }^{18}$

\section{Potential for Combination of Techniques}

Other librarians have made productive use, separately, of these two powerful techniques. Nominal analysis of use or nonuse eliminates some of the distortion produced by attempting to compare print circulation and electronic usage. And analysis of a collection's PEU allows librarians to learn those areas of a collection that are more likely meeting patrons' expectations. By combining nominal analysis of use and PEU 
into a single method, one can determine those disciplines where our patrons show a preference for print books or for e-books. These determinations can then be used within collection development to choose a format when funds are not available to buy a title in both formats.

\section{Methods}

The first step in the study was a nominal analysis of use for a comparable set of e-books and print books within the U of M collection. Following that, the PEU for disciplinary subsets corresponding to the academic units on campus was determined. Those disciplines with a PEU in one format or another that exceeded the mean by one standard deviation were determined to be strongly favored for purchase in that format.

\section{Dataset}

At U of M, the first e-books were purchased in 2001. Until 2013, all purchases were packages, and many included titles with publication dates prior to 2000 . To reduce the confounding effects of older titles with less likelihood of use, the dataset is limited to titles published in 2001 or later. Figure 1 shows the number of books in the collection published in each year.

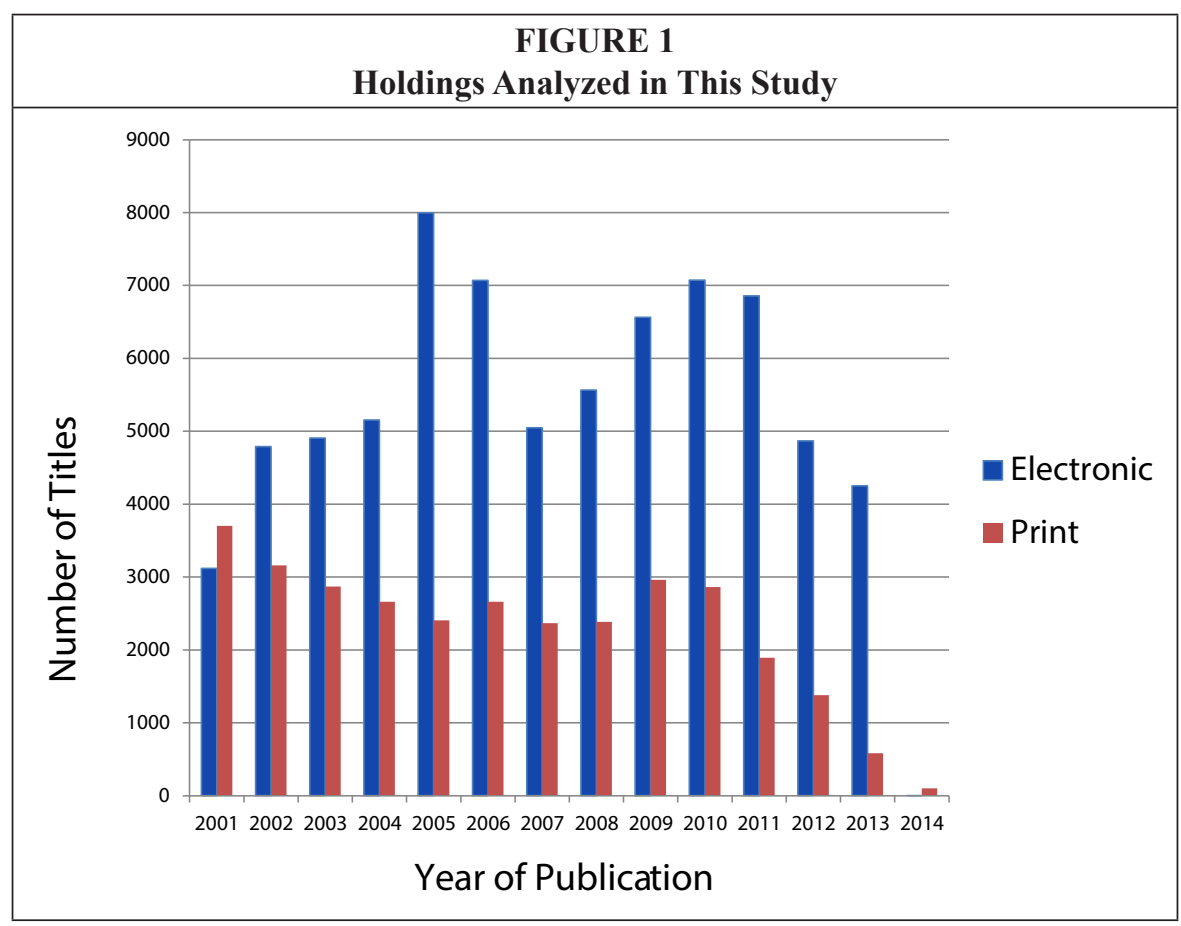

The dataset did not include all books in the collection published between 1990 and 2014. The following exclusions were made:

- E-books were limited to titles provided by EBSCO (formerly NetLibrary) and Springer. These constitute by far the bulk of our e-books, although we had purchased a few thousand titles from other vendors. EBSCO and Springer e-books have MARC records that include a Library of Congress Classification (LCC) number, which is essential to the analysis of the collection by discipline. 
Other providers do not have LCC numbers in the MARC records, at least in our integrated library system (ILS).

- Because our music library is housed in a branch location and its print collection was not included in this analysis, e-books with an LCC number beginning with " $\mathrm{M}$ " were excluded.

- Print books unavailable for circulation were excluded. At U of M, titles within the reference collection, professional collection (reserved for staff use), and Special Collections are restricted to "library use only."

All told, the dataset included 99,077 e-books and 92,101 print books.

\section{Coding for Nominal Analysis}

Queries were performed in the ILS to extract the dataset described above. Exported to an Excel spreadsheet were the LCC number, title, author, publication year, location code (used to determine whether a title was print or electronic), and for print books, circulation for the 2013-2014 academic year.

E-book usage reports were generated from the Springer and EBSCO administrative modules; along with title and author information, usage data were exported to an Excel spreadsheet. Both vendors provide usage statistics only in cases where at least one usage was recorded. For titles in the dataset for which vendors did not report a use figure, the value was assumed to be zero.

For the nominal analysis to be performed, the ILS data for e-books (specifically, the LCC number and publication year) needed to be merged with usage data from vendors onto a single line in the spreadsheet. Data from the usage report spreadsheet were copied into the ILS-generated spreadsheet. The resulting spreadsheet was sorted by title to bring the e-book usage data next to the ILS-generated data. (Using the "Duplicate Values" option of the "Highlight Cells Rule" under "Conditional Formatting" made it easy to recognize the repeated titles. See figure 2.) For purposes of nominal analysis,

\begin{tabular}{|c|c|c|c|c|c|c|c|}
\hline \multicolumn{8}{|c|}{$\begin{array}{r}\text { FIGURE } 2 \\
\text { Use of } 6 \text { " Dunlicate Values" in Frcel to }\end{array}$} \\
\hline & A & B & C & $\mathrm{D}$ & $E$ & $\mathrm{~F}$ & G \\
\hline 1 & $\begin{array}{l}\text { BROAD } \\
\text { CLASS }\end{array}$ & CLASS \# & TITLE & AUTHOR & PUB YEAR & LOCATION & YTDCIRC \\
\hline 2 & HA-HJ & HD9566.R & Addicted to oil: America's relentless dr & Rutledge, & 2005 & Electronic & NO \\
\hline 3 & $\mathrm{~B} / \mathrm{BC} / \mathrm{BD} /$ & BJ1533.D4 & Addiction and responsibility / edited by & Society for & 2011 & Electronic & NO \\
\hline 4 & $\mathrm{R}$ & RC564.A2 & Addiction counseling review: preparing & for compr & 2005 & Electronic & YES \\
\hline 5 & & & Addiction counseling review: preparing & for compr & 2005 & & 2 \\
\hline 6 & $\mathrm{HM}-\mathrm{HX}$ & HV4998.A & Addiction counselor's desk reference / & / Robert Ho & 2005 & Electronic & NO \\
\hline 7 & R & $\mathrm{RC5} 64 . \mathrm{A3}$ & Addiction medicine: science and practic & ce / Bankol & 2011 & Electronic & YES \\
\hline 8 & & & Addiction medicine: science and practic & ce / Bankole & le A. Johnso & n, editor. & 3 \\
\hline 9 & $\mathrm{HM}-\mathrm{HX}$ & HV4998.A & Addiction recovery management: theor & ry, research & 2011 & Electronic & NO \\
\hline 10 & $\mathrm{HM}-\mathrm{HX}$ & HV5801.H & Addiction: a disorder of choice / Gene & Heyman, $\mathrm{C}$ & 2009 & Electronic & NO \\
\hline 11 & $\mathrm{HM}-\mathrm{HX}$ & HV5825.P & Addiction: a reference encyclopedia / & Padwa, $\mathrm{Hc}$ & 2010 & Electronic & NO \\
\hline 12 & E & E98.L7 F74 & Addictions and Native Americans / Lat & French, Laf & 2000 & Electronic & YES \\
\hline 13 & & & Addictions and Native Americans / Lat & French, Lau & urence, 194 & & 4 \\
\hline 14 & TS & TS183.65 & Additive manufacturing technologies: $r$ & Gibson, I. ( & 2010 & Electronic & YES \\
\hline 15 & & & Additive manufacturing technologies: $r$ & Gibson, I. (1) & (lan) & & 2 \\
\hline 16 & |L & LC3733. N5 & Additive schooling in subtractive times & Bartlett, LA & 2011 & Electronic & NO \\
\hline & lent & ? & rith & ded as "N & Was , Title & YES & twice on \\
\hline
\end{tabular}


it was only necessary to record whether a book had been used. Whenever a title with usage was encountered, its corresponding line from the ILS report was coded "YES." The remaining titles (present in the ILS report, but with no usage recorded by the vendor) were coded "NO." At the end of coding, titles from the vendor usage report were deleted from the spreadsheet.

The main difficulty encountered in this phase of the study was the presence of multiple books in the ILS report with the same title (particularly conference proceedings). To clarify which edition had been used, it was necessary to return to the vendor's report, extract the International Standard Book Number (ISBN), and run a search in Amazon (the university's ILS could have been used as well) to identify the appropriate edition. Had ISBNs been exported from the ILS and matched to ISBNs in the vendors' usage reports, the coding would have gone faster. In fact, a VLOOKUP function would have generated the required data automatically.

For print books, any title with a circulation figure other than zero was coded "YES." Titles with a circulation of zero were coded "NO."

Finally, to identify the discipline under which a title falls, the list was sorted by LCC number. The titles were grouped according to the distribution shown in table 2.

\begin{tabular}{|c|c|c|c|}
\hline \multicolumn{4}{|c|}{$\begin{array}{c}\text { TABLE } 2 \\
\text { Disciplines According to Library of Congress Classification }\end{array}$} \\
\hline Discipline & $\begin{array}{l}\text { LCC Number } \\
\text { Range }\end{array}$ & Discipline & $\begin{array}{l}\text { LCC Number } \\
\text { Range }\end{array}$ \\
\hline General Works & A & Literature (General) & $\mathrm{PN}$ \\
\hline Philosophy & $\begin{array}{l}\mathrm{B}, \mathrm{BC}, \mathrm{BD}, \\
\mathrm{BH}, \mathrm{BJ}\end{array}$ & $\begin{array}{l}\text { Literature, American \& } \\
\text { English }\end{array}$ & PR-PS \\
\hline Psychology & $\mathrm{BF}$ & Science (General) & Q \\
\hline Religion & BL-BX & \multirow[t]{2}{*}{ Mathematics } & \multirow{2}{*}{$\begin{array}{l}\text { QA (all except } \\
71-90)\end{array}$} \\
\hline History & $\mathrm{C}-\mathrm{F}$ & & \\
\hline Earth Sciences & G-GE, QE & Computer Science & QA71-90 \\
\hline Anthropology & GF-GV & Astronomy & QB \\
\hline Social Sciences (General) & $\mathrm{H}$ & Physics & QC \\
\hline \multirow{2}{*}{$\begin{array}{l}\text { Business, Economics, \& } \\
\text { Finance }\end{array}$} & \multirow{2}{*}{ HA-HJ } & Chemistry & QD \\
\hline & & \multirow[t]{2}{*}{ Biology } & \multirow{2}{*}{$\begin{array}{l}\text { QH-QK-QL- } \\
\text { QR }\end{array}$} \\
\hline Sociology & HM-HX & & \\
\hline Political Science & $\mathrm{J}$ & Anatomy \& Physiology & QM-QP \\
\hline Law & $\mathrm{K}$ & Medicine/Nursing & $\mathrm{R}$ \\
\hline Education & $\mathrm{L}$ & Agriculture & $\mathrm{S}$ \\
\hline Art & $\mathrm{N}, \mathrm{TR}, \mathrm{TT}$ & Engineering & T, TA-TP, TS \\
\hline Linguistics & $\mathrm{P}$ & Home Economics & $\mathrm{TX}$ \\
\hline \multirow{2}{*}{$\begin{array}{l}\text { Literature and Languages, } \\
\text { Non-English }\end{array}$} & \multirow[t]{2}{*}{ PA-PQ, PT } & Military \& Naval Science & $\mathrm{U}, \mathrm{V}$ \\
\hline & & Librarianship & Z \\
\hline
\end{tabular}

\section{Percentage of Expected Use (PEU)}

To determine whether a format experienced use above or below the PEU, it was necessary to calculate the percentage of the total collection that each discipline comprised. 
Following that, the percentage of titles used in each format, by discipline, was also recorded. (A pivot table automatically counted the number of titles coded "YES" in each discipline.) The second figure was divided by the first, creating a PEU. The PEU was calculated separately for each discipline in each format.

Because PEU is influenced by the strength of a collection in a discipline, that strength may confound attempts to measure patron preferences for a format. To counter that effect, the lower PEU within a discipline for a format was subtracted from the higher PEU within a discipline. For example, in History the print collection had a PEU of 134, meaning that the print books were used at a rate 1.3 times their proportion of the print collection. The e-books in History had a PEU of 102. Subtracting 102 from 134 leaves a "gap" of 32. The distance between the PEUs of the two formats is an indicator of the strength of patron preference for a format.

Again, a chi-square test allows us to determine whether the differences between the PEUs are statistically significant. A $p$ value of less than .05 is statistically significant, and $p$ values near .05 are approaching significance. For those disciplines where the $p$ value is not statistically significant, we cannot say with confidence that our test produces meaningful information about patron preferences. Therefore, table 3 only includes those disciplines where the differences are significant or approaching significance.

Picturing the PEU scores as points on a number line, as in figure 3, may help to illustrate why the distance between them is strong indicator of collective preference for a format within a discipline.

Aguilar recommends that scores exceeding one standard deviation from the mean should be used to indicate disciplines with strong under- or overperformance. Using that criterion, one can identify those disciplines where patron preference for a format was strongest. Determining the mean and its standard deviation for each format required dividing the disciplines into two groups. The group of disciplines where print had a higher PEU showed a standard deviation of 24 for the "gap" score. The group

\begin{tabular}{|l} 
FIGURE 3 \\
Graphical Representation of Distance Between PEU Scores by Format \\
\hline PEU
\end{tabular}


of disciplines where electronic had a higher PEU showed a standard deviation of 29 for the "gap" score.

\section{Results}

Overall, patrons at $\mathrm{U}$ of $\mathrm{M}$ showed a preference for print materials. Of all the titles analyzed in all formats, 12.1 percent were used at least once in the 2013-2014 academic year. Averaged across all disciplines, 16.1 percent of print titles were used, and only 10.4 percent of electronic titles. Averaged across all disciplines, print titles had a PEU of 133 , and electronic titles had a PEU of 86.

This technique allowed identification of several disciplines where patrons showed a strong preference for one format over another. Table 3 shows the disciplines, sorted by the strength of demonstrated format preference.

\begin{tabular}{|c|c|c|c|c|c|c|}
\hline \multicolumn{7}{|c|}{$\begin{array}{c}\text { TABLE } 3 \\
\text { Comparison of Distribution of Materials by Format and PEU by Format }\end{array}$} \\
\hline Broad Class & $\begin{array}{l}\text { E-books as } \\
\% \text { of All } \\
\text { Books in } \\
\text { Discipline }\end{array}$ & $\begin{array}{l}\text { PEU For } \\
\text { E-books }\end{array}$ & $\begin{array}{c}\text { Print } \\
\text { Books as } \\
\% \text { of All } \\
\text { Books in } \\
\text { Discipline }\end{array}$ & \begin{tabular}{|} 
PEU For \\
Print \\
Books
\end{tabular} & $\begin{array}{c}\text { Gap in } \\
\text { Distribution }\end{array}$ & $\begin{array}{l}\text { Gap in } \\
\text { PEU }\end{array}$ \\
\hline $\begin{array}{l}\text { Social Sciences } \\
\text { (General) }\end{array}$ & $40 \%$ & $180 \%$ & $60 \%$ & $270 \%$ & $-20 \%$ & $-90 \%$ \\
\hline $\begin{array}{l}\text { Literature, Am. } \\
\& \text { English }\end{array}$ & $31 \%$ & $137 \%$ & $69 \%$ & $95 \%$ & $-38 \%$ & $42 \%$ \\
\hline Anthropology & $51 \%$ & $118 \%$ & $49 \%$ & $97 \%$ & $2 \%$ & $21 \%$ \\
\hline $\begin{array}{l}\text { Military \& } \\
\text { Naval Science }\end{array}$ & $48 \%$ & $44 \%$ & $52 \%$ & $28 \%$ & $-5 \%$ & $16 \%$ \\
\hline Art & $30 \%$ & $93 \%$ & $70 \%$ & $83 \%$ & $-40 \%$ & $10 \%$ \\
\hline $\begin{array}{l}\text { Lit. \& Lang., } \\
\text { Non-English }\end{array}$ & $44 \%$ & $94 \%$ & $56 \%$ & $85 \%$ & $-11 \%$ & $9 \%$ \\
\hline $\begin{array}{l}\text { Home } \\
\text { Economics }\end{array}$ & $45 \%$ & $92 \%$ & $55 \%$ & $95 \%$ & $-9 \%$ & $-3 \%$ \\
\hline General Works & $37 \%$ & $99 \%$ & $63 \%$ & $102 \%$ & $-26 \%$ & $-3 \%$ \\
\hline History & $51 \%$ & $102 \%$ & $49 \%$ & $134 \%$ & $2 \%$ & $-32 \%$ \\
\hline Psychology & $53 \%$ & $180 \%$ & $47 \%$ & $109 \%$ & $5 \%$ & $70 \%$ \\
\hline $\begin{array}{l}\text { Literature } \\
(\text { General })\end{array}$ & $56 \%$ & $109 \%$ & $44 \%$ & $78 \%$ & $12 \%$ & $31 \%$ \\
\hline Sociology & $58 \%$ & $163 \%$ & $42 \%$ & $133 \%$ & $16 \%$ & $30 \%$ \\
\hline Philosophy & $59 \%$ & $122 \%$ & $41 \%$ & $104 \%$ & $17 \%$ & $18 \%$ \\
\hline Linguistics & $59 \%$ & $146 \%$ & $41 \%$ & $114 \%$ & $19 \%$ & $32 \%$ \\
\hline Political Science & $62 \%$ & $72 \%$ & $38 \%$ & $67 \%$ & $25 \%$ & $5 \%$ \\
\hline Education & $64 \%$ & $189 \%$ & $36 \%$ & $98 \%$ & $28 \%$ & $91 \%$ \\
\hline \multicolumn{7}{|c|}{$\begin{array}{l}\text { Negative numbers in "Gap in Distribution" mean that print books outnumber e-books; positive } \\
\text { numbers mean that e-books outnumber print books. } \\
\text { Negative numbers in "Gap in PEU" mean that the PEU for print books is higher than the PEU for } \\
\text { e-books; positive numbers mean that the PEU for e-books is higher than the PEU for print books. }\end{array}$} \\
\hline
\end{tabular}




\begin{tabular}{|c|c|c|c|c|c|c|}
\hline \multicolumn{7}{|c|}{$\begin{array}{c}\text { TABLE } 3 \\
\text { Comparison of Distribution of Materials by Format and PEU by Format }\end{array}$} \\
\hline Broad Class & $\begin{array}{l}\text { E-books as } \\
\% \text { of All } \\
\text { Books in } \\
\text { Discipline }\end{array}$ & $\begin{array}{l}\text { PEU For } \\
\text { E-books }\end{array}$ & $\begin{array}{c}\text { Print } \\
\text { Books as } \\
\% \text { of All } \\
\text { Books in } \\
\text { Discipline }\end{array}$ & $\begin{array}{l}\text { PEU For } \\
\text { Print } \\
\text { Books }\end{array}$ & $\begin{array}{l}\text { Gap in } \\
\text { Distribution }\end{array}$ & $\begin{array}{l}\text { Gap in } \\
\text { PEU }\end{array}$ \\
\hline Religion & $65 \%$ & $90 \%$ & $35 \%$ & $118 \%$ & $29 \%$ & $-28 \%$ \\
\hline Librarianship & $65 \%$ & $98 \%$ & $35 \%$ & $74 \%$ & $30 \%$ & $23 \%$ \\
\hline Chemistry & $70 \%$ & $58 \%$ & $30 \%$ & $48 \%$ & $39 \%$ & $11 \%$ \\
\hline Earth Science & $71 \%$ & $123 \%$ & $29 \%$ & $49 \%$ & $42 \%$ & $74 \%$ \\
\hline Biology & $74 \%$ & $88 \%$ & $26 \%$ & $42 \%$ & $49 \%$ & $45 \%$ \\
\hline $\begin{array}{l}\text { Medicine/ } \\
\text { Nursing }\end{array}$ & $77 \%$ & $114 \%$ & $23 \%$ & $128 \%$ & $53 \%$ & $-14 \%$ \\
\hline $\begin{array}{l}\text { Business, Econ., } \\
\& \text { Finance }\end{array}$ & $78 \%$ & $80 \%$ & $22 \%$ & $86 \%$ & $55 \%$ & $-6 \%$ \\
\hline Law & $78 \%$ & $63 \%$ & $22 \%$ & $98 \%$ & $56 \%$ & $-35 \%$ \\
\hline $\begin{array}{l}\text { Anatomy \& } \\
\text { Physiology }\end{array}$ & $80 \%$ & $102 \%$ & $20 \%$ & $74 \%$ & $60 \%$ & $28 \%$ \\
\hline Mathematics & $84 \%$ & $97 \%$ & $16 \%$ & $106 \%$ & $68 \%$ & $-8 \%$ \\
\hline Engineering & $85 \%$ & $69 \%$ & $15 \%$ & $82 \%$ & $70 \%$ & $-82 \%$ \\
\hline Agriculture & $87 \%$ & $58 \%$ & $13 \%$ & $73 \%$ & $75 \%$ & $-15 \%$ \\
\hline $\begin{array}{l}\text { Science } \\
\text { (General) }\end{array}$ & $88 \%$ & $128 \%$ & $12 \%$ & $125 \%$ & $75 \%$ & $3 \%$ \\
\hline Physics & $88 \%$ & $49 \%$ & $12 \%$ & $43 \%$ & $76 \%$ & $6 \%$ \\
\hline Astronomy & $93 \%$ & $98 \%$ & $7 \%$ & $42 \%$ & $86 \%$ & $56 \%$ \\
\hline $\begin{array}{l}\text { Computer } \\
\text { Science }\end{array}$ & $95 \%$ & $103 \%$ & $5 \%$ & $126 \%$ & $89 \%$ & $-23 \%$ \\
\hline All Disciplines & $69 \%$ & $86 \%$ & $31 \%$ & $133 \%$ & $38 \%$ & $-47 \%$ \\
\hline \multicolumn{7}{|c|}{$\begin{array}{l}\text { Negative numbers in "Gap in Distribution" mean that print books outnumber e-books; positive } \\
\text { numbers mean that e-books outnumber print books. } \\
\text { Negative numbers in "Gap in PEU" mean that the PEU for print books is higher than the PEU for } \\
\text { e-books; positive numbers mean that the PEU for e-books is higher than the PEU for print books. }\end{array}$} \\
\hline
\end{tabular}

Results produced by this method are not conclusive about all users in all disciplines. There are many reasons aside from simple preference that a user may choose a book in a particular format. Obviously, if a book is only available in one format, that may dictate use more than preference does. For example, disciplines where a large portion of the books are in electronic format may see a higher PEU for e-books simply because the preponderance of material is in that format.

However, at $\mathrm{U}$ of $\mathrm{M}$, preference does seem to have more influence than availability in dictating format choice. Table 4 shows the distribution of books according to format in various disciplines, along with the PEU in each format. The same data are displayed graphically in figure 4 . If the hypothesis that relative strength of a format influences user preferences were valid, one would expect to see a correlation between the percentage of a discipline's collection in a format and that format's PEU. There is only a very 
weak correlation. Calculation of the Pearson product-moment correlation coefficient for these data gives a value of $R$ as -0.0757 ; the nearer the $R$ is to zero, the weaker the correlation. It seems likely that other reasons for choosing a format outweigh the simple question of availability of more titles in a particular format.

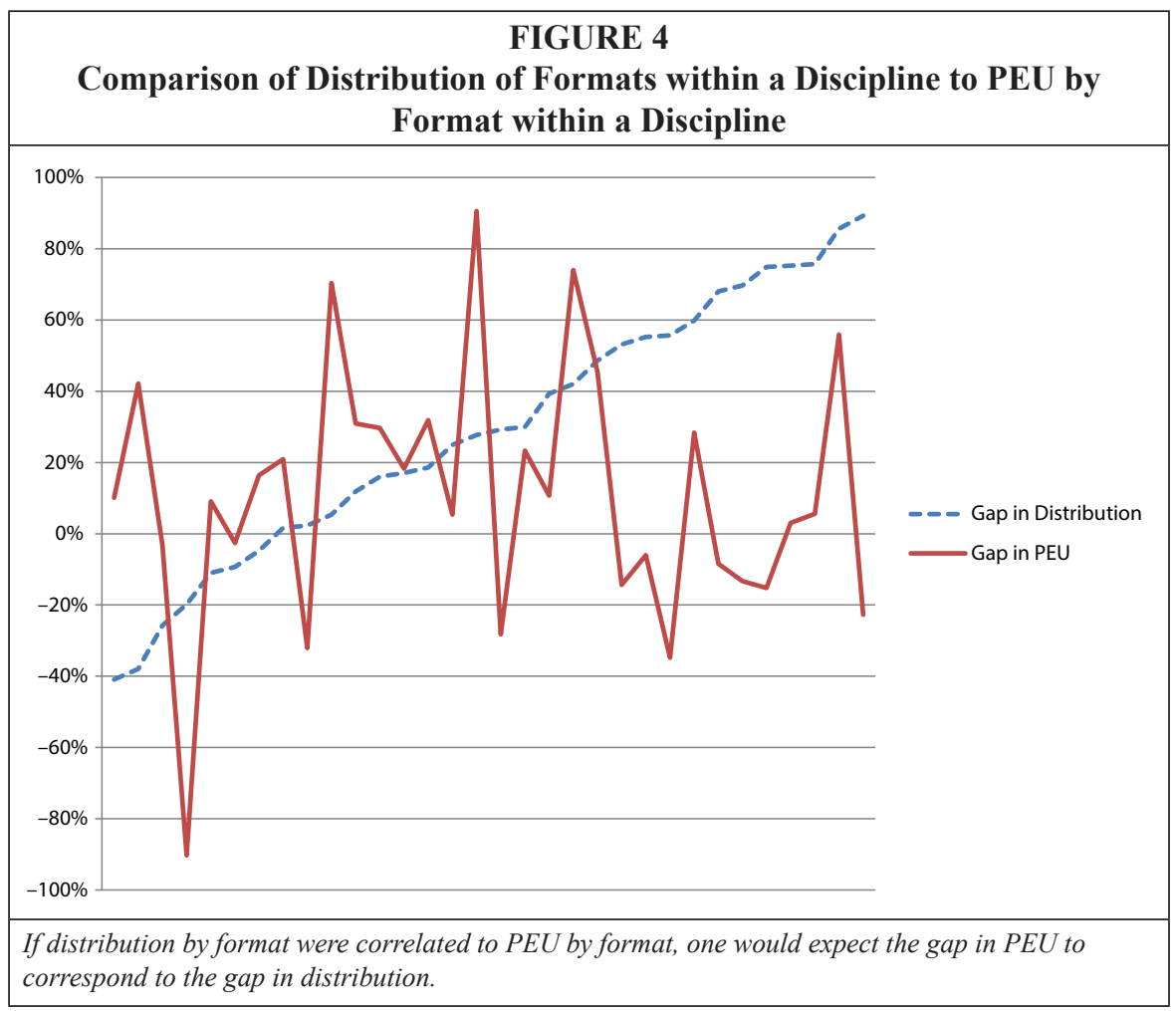

\section{Discussion}

In some ways, this exercise confirmed suspicions based on experiences speaking with patrons. Humanists prefer reading print books because print books lend themselves to extended argument and deeper comprehension; ${ }^{19}$ this is supported by Levine-Clark's findings about e-book usage among humanists being lower than among scholars in other disciplines. ${ }^{20}$ And some of the scientists show a strong preference for e-books, because e-books offer ease of reference and searchability for key terms.

The preference for print books among mathematicians and for e-books among students of education did defy preconceptions. However, the status of education students among the users who most favor e-books corroborates the findings of a survey performed by Corlett-Rivera and Hackman. ${ }^{21}$

Revelle et al. demonstrated that there are four types of academic readers: Book Lovers, Technophiles, Pragmatists, and Printers, each with a distinct approach to preferring a format for their books. ${ }^{22}$ The distribution of those opinion types among academic departments does not completely account for the format preferences demonstrated in U of M's collection. For example, Book Lovers are the most common type of reader among scholars in the humanities and the fine arts, and Technophiles are the plurality of engineers and business scholars. Yet, readers in the arts, engineering, and business 
do not show a marked preference for one format over another at $U$ of $M$. Our humanist readers do show a strong preference for print books in history and religion.

One thought was that some of the demonstrated preference for e-books in certain disciplines might be caused by disproportionate enrollment in online classes in those disciplines. However, online enrollment roughly tracks all enrollment in terms of proportions of various majors. ${ }^{23}$

A factor that should also be considered when judging the overall preference for print books is the difference in how the two formats have been selected. Print books have long been chosen individually by librarians, often acting at the behest of teaching or research faculty on campus. Until 2013, all e-books were purchased as large sets. Those large sets, usually numbering many thousands of titles, were not subject to the same level of scrutiny by librarians as the individually selected print books. Lamothe has found that e-books purchased in bundles have less usage than individually selected e-books. ${ }^{24}$ On the other hand, studies comparing circulation of librarian-selected books versus those purchased through approval plans offer conflicting results, with some demonstrating higher use of librarians' selections, and others demonstrating the opposite. ${ }^{25}$ The e-book bundles may be comparable to approval plan book lists.

An additional factor to be considered when interpreting these results is the demographic makeup of each disciplinary cohort. Lamothe has demonstrated a variation of affinity for e-books by enrollment status: "Doctoral students exhibited the strongest relationship with e-book usage, while undergraduate students showed signs of the weakest. Faculty demonstrated the overall weakest relationship with e-book usage." 26 Those disciplines where undergraduates are a higher percentage of the student body will show a lower overall use of e-books, based on the distribution of their population of likely users.

As seen, the results delivered by the two-step method at $\mathrm{U}$ of $\mathrm{M}$ show that our users' preferences vary in some cases from typical preferences according to disciplines, as determined by researchers using other methods. To gain more insight into why and how our users allow the format of books to influence their decisions about using them, focus group studies are a sensible next step. Discussions in a focus group may offer insights not directly available from data analysis.

Despite these potential confounding factors, the findings of this study have implications for collection development at $U$ of $M$. For those disciplines with a marked preference for e-books, we will continue to purchase in that format. And for those with a marked preference for print, we will avoid e-books completely. For disciplines in the middle, factors other than reader preference can be given more weight. For example, because we value both preservation and participation in interlibrary loan, we will tend toward purchasing print books in most disciplines. And, when e-book packages are offered for sale, we will concentrate our funds in those areas where e-books have proven popular.

Despite asserting the implications for our own institution's collection development practices with such confidence, this method is useful mostly for libraries operating on the lagging edge of e-books acquisitions. The information about aggregate user preferences is mostly useful to librarians serving as intermediaries between requestors and vendors, or purchasing books in anticipation of future use. As libraries move toward patron-driven acquisitions (PDA), individual user preferences may drive decision making more than librarians do.

However, PDA brings its own need for understanding collective format preferences. The easiest method of implementing PDA is centered on e-books; PDA programs that allow patrons to choose print books are less common and more labor-intensive. But if librarians blithely steer patrons toward e-books even in those fields where patrons 
have demonstrated a collective preference for print books, they may be unwittingly deterring use by making a majority of new titles available only in formats their patrons are disinclined to read.

Finally, it is worth noting that this method produces a "snapshot" of user preferences at a particular moment. What users in 2013 preferred may not be what they prefer in 2020. Therefore, a good practice would be to replicate the study every few years to obtain a current understanding of user preferences.

\section{Conclusion}

Librarians often consider patron preferences when choosing a format for monographic purchases. Determining those preferences has proved difficult, because standard measures of interest like circulation and electronic usage are not directly comparable. However, combining the proven techniques of a nominal test of use versus nonuse with PEU creates a new two-step test to show when a library's patrons exhibit a strong preference for one format within a discipline.

At $\mathrm{U}$ of $\mathrm{M}$, the overall preference for print, combined with the drawbacks of e-books for preservation and resource sharing, leads to a recommendation that most monographic purchases be in print, except for those areas where patrons exhibit a strong preference for e-books. Librarians at other institutions may find their results will vary, but this conceptually simple (if time-consuming) test may prove helpful in learning more about patron preferences across various disciplines.

\section{Acknowledgements}

The author is indebted to George Relyea for his statistical analysis. This model was originally presented at the Tenn-Share Fall Conference in Nashville, September 26, 2014.

\section{Notes}

1. For a discussion of the pros and cons of each format, please see Steven A. Knowlton, "Print, Electronic, or Both? How Libraries Choose a Format When Purchasing Books," Tennessee Libraries 64, no. 2 (2014), available online at www.tnla.org/?page=TL64_2_formats [accessed 3 November 2014].

2. Among other studies, see Wendy Allen Shelburne, "E-Book Usage in an Academic Library: User Attitudes and Behaviors," Library Collections, Acquisitions, and Technical Services 33 (2009): 59-72; David B. Daniel and William Douglas Woody, "E-Textbooks at What Cost? Performance and Use of Electronic v. Print Texts," Computers E Education 62 (2013): 18-23; Nichole Buzzetto-More, Retta Sweat-Guy, and Muna Elobaid, "Reading in A Digital Age: e-Books-Are Students Ready for This Learning Object?" Interdisciplinary Journal of Knowledge and Learning Objects 3 (2007); Peter Hernon, Rosita Hopper, Michael R. Leach, Laura L. Saunders, and Jane Zhang, "E-book Use by Students: Undergraduates in Economics, Literature, and Nursing," Journal of Academic Librarianship 33, no. 1 (2007): 3-13; William Douglas Woody, David B. Daniel, and Crystal A. Baker, "E-Books or Textbooks: Students Prefer Textbooks," Computers \& Education 55 (2010): 945-948.

3. Erin L. Ellis, Nikhat J. Ghouse, Monica Claassen-Wilson, John M. Stratton, and Susanne K. Clement, "Comparing Approval and Librarian-Selected Monographs: An Analysis of Use," in Library Data: Empowering Practice and Persuasion, ed. Darby Orcutt (Santa Barbara, Calif.: Libraries Unlimited, 2010), 53-68.

4. Some critiques of circulation measurement as a tool for collection analysis include Francine Fialkoff, "The Circulation Trap," Library Journal 127, no. 13 (Aug. 15, 2002): 68; R. Toby Greenwalt, "In Search of Better Metrics," Public Libraries 52, no. 2 (Mar. 2013): 22-26; Peggy Johnson, Fundamentals of Collection Development and Management, 2nd ed. (Chicago: American Library Association, 2009), 248-49.

5. For examples of this approach, see Debbi Dinkins, "Circulation as Assessment: Collection Development Policies Evaluated in Terms of Circulation at a Small Academic Library," College and Research Libraries 64, no. 1 (2003): 46-53; Brian Adams and Bob Noel, "Circulation Statistics in the Evaluation of Collection Development," Collection Building 27, no. 2 (2008): 71-73; Hil- 
ary Davis and Annette Day, "Data-informed Collection Management at the NCSU Libraries," Against The Grain 24, no. 4 (2012): 18-24; Millie L. Jackson and Beth Holley, "The Evolving Role of E-Books at The University of Alabama Libraries," Serials Librarian 61, no. 2 (2011): 200-06; Jennifer E. Knievel, Heather Wicht, and Lynn Silipigni Connaway, "Use of Circulation Statistics and Interlibrary Loan Data in Collection Management," College \& Research Libraries 67, no. 1 (2006): 35-49; Jonathan Nabe, "Are We Spending Too Much on Print STEM Monographs? A Method and Analysis for Improving Monograph Allocations Based on Circulation Statistics," Issues in Science E Technology Librarianship no. 73 (2013), available online at www.istl.org/13-summer/refereed1. html [accessed 3 November 2014]; Lisa M. Rose-Wiles, "Are Print Books Dead? An Investigation of Book Circulation at a Mid-Sized Academic Library," Technical Services Quarterly 30 (2013): 129-52; Peter B. Shirts, "Using Circulation and Interlibrary Loan Statistics to Inform Subsection-level Collection Development in an Academic Branch Music Library" (master's thesis, University of North Carolina-Chapel Hill, 2014).

6. Cathy Goodwin, "The e-Duke Scholarly Collection: E-book vs. Print Use," Collection Building 33, no. 4 (2014): 101-05.

7. K.J. McConway, "Marginalization," in Encyclopedia of Statistical Sciences, eds. Samuel Kotz and Norman L. Johnson (New York: Wiley, 1985), vol. 5, 221-23.

8. Lynn Silipigni Connaway, Kaia L. Densch, and Susan Gibbons, "The Integration and Usage of Electronic Books (eBooks) in the Digital Library," in Computers in Libraries 2002: Collected Presentations, compiled by Carol Nixon (Medford, N.J.: Information Today, 2002), 18-25.

9. Justin Littman and Lynn Silipigni Connaway, "A Circulation Analysis of Print and E-books in an Academic Research Library," Library Resources and Technical Services 48, no. 4 (2004): 256-62.

10. Marilyn Christianson and Marsha Aucoin, "Electronic or Print Books: Which Are Used?" Library Collections, Acquisitions, \& Technical Services 29 (2005): 74-79.

11. Karen Carter Williams and Rickey Best, "E-Book Usage and the Choice Outstanding Academic Book List: Is There a Correlation?" Journal of Academic Librarianship 32, no. 5 (2006): 474-78.

12. Robert Slater, "E-books or Print Books, 'Big Deals' or Local Selections-What Gets More Use?" Library Collections, Acquisitions, \& Technical Services 33 (2009): 31-41.

13. Terry Bucknell, "The 'Big Deal' Approach to Acquiring E-books: A Usage-Based Study," Serials 23, no. 2 (2010): 126-34.

14. Lisa M. Rose-Wiles, "Are Prints Books Dead? An Investigation of Book Circulation at a Mid-Sized Academic Library," Technical Services Quarterly 30 (2013): 129-52.

15. George S. Bonn, "Evaluation of the Collection," Library Trends 22 (1974): 273.

16. Terry R. Mills, "The University of Illinois Film Center Collection Use Study" (ERIC report no. ED 227281,1982$)$.

17. William Aguilar, "The Application of Relative Use and Interlibrary Demand in Collection Development," Collection Management 8, no. 1 (1986): 15-24.

18. John N. Ochola, "Use of Circulation Statistics and Interlibrary Loan Data in Collection Management," Collection Management 27, no.1 (2003): 1-13.

19. For a summary of the research on comprehension and retention of materials in print and electronic formats, see Ferris Jabr, "Why the Brain Prefers Paper," Scientific American 309 (Nov. 2013): 48-53.

20. Michael Levine-Clark, "Electronic Book Usage: A Survey at the University of Denver," portal: Libraries and the Academy 6, no. 3 (2006): 285-99.

21. Kelsey Corlett-Rivera and Timothy Hackman, "E-Book Use and Attitudes in the Humanities, Social Sciences, and Education," portal: Libraries and the Academy 14, no. 2 (2014): 255-86.

22. Andy Revelle, Kevin Messner, Aaron Shrimplin, and Susan Hurst, "Book Lovers, Technophiles, Pragmatists, and Printers: The Social and Demographic Structure of User Attitudes toward e-Books," College and Research Libraries 73, no. 5 (2012): 420-29.

23. Based upon reports generated from the University of Memphis Office of Institutional Research.

24. Alain R. Lamothe, "Comparing Usage between Selective and Bundled E-Monograph Purchases," Collection Building 32, no. 3 (2013): 116-21.

25. See, for example, James Cory Tucker, "Collection Assessment of Monograph Purchases at the University of Nevada, Las Vegas Libraries," Collection Management 34, no. 3 (July 2009): 157-81; David C. Tyler, Christina Falci, Joyce C. Melvin, MaryLou Epp, and Anita M. Kreps, "Patron-Driven Acquisition and Circulation at an Academic Library: Interaction Effects and Circulation Performance of Print Books Acquired via Librarians' Orders, Approval Plans, and Patrons' Interlibrary Loan Requests," Collection Management 38, no. 1 (Jan. 2013): 3-32.

26. Alain R. Lamothe, "Factors Influencing the Usage of an Electronic Book Collection: Size of the E-book Collection, the Student Population, and the Faculty Population," College and Research Libraries 74, no. 1 (2013): 39. 